\title{
A Multimethod Approach to Assess and Measure Corporate Social Responsibility Disclosure and Practices in a Developing Economy
}

\author{
Sadaf Ehsan ${ }^{1, *}$, Mian Sajid Nazir ${ }^{1}$ (1), Mohammad Nurunnabi ${ }^{2,3, *(1)}$, Qasim Raza Khan ${ }^{1}$, \\ Samya Tahir ${ }^{1}$ and Ishfaq Ahmed ${ }^{4}$ \\ 1 Department of Management Sciences, COMSATS University Islamabad, Lahore Campus, Punjab 54000, \\ Pakistan; snazir@cuilahore.edu.pk (M.S.N.); qasimraza@cuilahore.edu.pk (Q.R.K.); \\ samyatahir@cuilahore.edu.pk (S.T.) \\ 2 Department of Accounting, Prince Sultan University, P.O. Box 66833, Riyadh 11586, Saudi Arabia \\ 3 St Antony's College, University of Oxford, 62 Woodstock Road, Oxford OX2 6JF, UK \\ 4 Hailey College of Commerce, University of the Punjab, Lahore, Punjab 54000, Pakistan; \\ ishfaqahmed@hcc.edu.pk \\ * Correspondence: sadafehsan@cuilahore.edu.pk (S.E.); \\ mnurunnabi@psu.edu.sa or mohammad.nurunnabi@sant.ox.ac.uk (M.N.)
}

Received: 31 July 2018; Accepted: 16 August 2018; Published: 20 August 2018

\begin{abstract}
Disclosures on Corporate Social Responsibility (CSR) practices of business organizations have heightened over the past few decades due to increased awareness. Major contributions in the literature on CSR practices and their disclosures come from the studies conducted in the developed world, while many developing economies like Pakistan remain under-researched and fewer revelations have been made about their CSR practices. Therefore, the present study aims to explore various aspects of CSR practices of Pakistani firms and their reporting trends. A multimethod approach has been adopted to measure CSR practices with respect to both approaches, quantitative and qualitative, for 170 listed firms from 2008 to 2015 . First, content analysis is employed to develop a CSR Disclosure Index (CSRD Index) as well as five sub indices, i.e., community welfare, health and education, environment and energy, product, and customer and workforce. Second, a multidimensional financial approach is used to calculate firm's CSR monetary spending ratio (CSR-MSR) using the monetary data of CSR activities. Results suggested that most Pakistani firms disclose more information about their product-, customer-, and stakeholder-related CSR activities and put less emphasis on health and education responsibilities. Moreover, there is a strong impact of government reforms on both the firm's CSR disclosures and monetary giving.
\end{abstract}

Keywords: corporate social responsibility; developing economies; multimethod approach; content analysis; multidimensional financial approach

\section{Introduction}

In recent years, the concept of Corporate Social Responsibility (CSR) emerged as one of the most important concerns for management and has become the important subject of scholarly debate [1]. Due to the increased awareness and attention of public, media, academic, and regulatory bodies, the importance of CSR practices of business organizations and their reporting has heightened over the past few decades. In response to this, corporations are increasingly disclosing information about their CSR practices to satisfy a wide range of interests from various stakeholders to establish the positive image in the market and society. These CSR practices are important parameters for the sustainable development of the business and for its value creation [2]. Because of the benefit of firms' CSR practices, all their 
direct and indirect stakeholders—such as employees, customers, environment, and society-that play the vital role in firms value creation. In order to gain positive support from stakeholders, firms are sharing more information about their CSR practices. CSR disclosure helps firms improve their corporate image and transparency as well as boost investors' confidence for investment decisions [3].

Despite the rising concern for firms' CSR practices and their disclosures, the majority of existing studies have been conducted in developed countries. Nonetheless, the context of developing countries offers plentiful opportunities for CSR activities as it is characterized by ever-spreading poverty, disparity, corruption, social mistreatment, hygienic disorders, and ecological contamination [4]. Yet, the literature lacks attention towards CSR practices when it comes to developing nations [5-7]. Complementing the previous argument, Buhmann (2005) states, "so far in the research literature more attention has been paid to CSR in Europe, Australia/New Zealand, and North America than elsewhere". Another study by Pisani, Kourula [8] concluded that less than $10 \%$ of the CSR literature comes from the studies conducted in developing world.

Moreover, the measurement of CSR is an important and most difficult task in conducting CSR research. CSR is a complex, multidimensional concept, and one can question whether every dimension is quantifiable, let alone suitable for aggregation [9]. There is a large number of studies that propose different measures of CSR [10-13]. These studies propose different perspectives and dimensions of CSR, like community, people, employees, product quality, environment, society, education, and health services. However, what should and should not be included in order to establish the comprehensive and indicative measure of CSR is still a debatable question for academics, researchers, and policy-makers $[14,15]$. These criticalities exist because most of these studies do not incorporate the contextual factors that can influence the CSR practices of firms $[16,17]$ and their measurement. Context holds great importance in CSR studies because every country is unique in its own social, cultural, political, economic, and institutional context. Therefore, it is very important to consider the contextual factors while developing the instrument for CSR measurement.

This state of affairs reveals that there is still a huge gap in the literature with regard to firms' CSR disclosure practices and their measurement in developing countries [16,18,19]. Ali, Frynas [20] argued that this area of research has not been fully developed because of the differences in CSR disclosure practices between developed and developing economies, which can be attributed to differences in their context [21]. Another potential reason for this lack of CSR research in the context of developing countries is due to less pressure from public, regulatory bodies, and domestic actors on business organizations to disclose information about their CSR practices [20,22]. This situation restricts the availability of CSR data for conducting empirical research and makes CSR research 'a tough row to hoe' in developing economies [23]. Moreover, numerous previous studies on CSR that have been done in developing economies have identified that lack of CSR education and support from CSR-promoting institutions are other major reasons for narrow research in CSR disclosures [19,24]. Above all, the cost of disclosing/reporting CSR information is another major factor in developing countries due to the lack of resources and motivation that hampers CSR research greatly [25]. Therefore, there is a strong need to explore CSR activities of firms and their disclosures to promote CSR research, particularly in the context of a developing economy like Pakistan.

To fill this gap, the present study aims to explore the various aspects of CSR practices of Pakistani firms and their disclosure trends. This study contributes to the existing literature on CSR practices and disclosures in several ways. Firstly, as far as can be ascertained, it is the first study of its kind that collects the relatively large dataset of 170 firms for eight years listed on h Pakistan Stock Exchange (formerly Karachi Stock Exchange). Previous studies on CSR disclosures employed very small samples, due to which their results are not safely generalizable. For instance, Mian [26] conducted a case study in which he explored the CSRD of only three fertilizer firms. Sharif and Rashid [27] examined 22 Pakistani commercial banks. Recently, Malik and Kanwal [7] used the sample of nine pharmaceutical firms to examine CSR disclosures. Secondly, the present study contributes in the methodological measurement of CSR practices of firms using a multimethod approach. Previous studies used either a 
qualitative or quantitative aspect to measure CSR. Third, this is the first kind of empirical study on its own that developed a comprehensive scale for the measurement of CSR in developing economies. This can help the future studies to empirically investigate the different aspects of CSR research and draw sound inferences.

After this introduction, rest of the paper is categorized as: Section 2 briefly discusses the CSR in a Pakistani context. Section 3 shed light on exiting approaches to measure CSR. Section 4 is based on methodology. Results and discussions are presented in Section 5. The final section concludes the overall study, gives policy implications, and suggests some recommendations for future research.

\section{Corporate Social Responsibility in Pakistani Context}

Pakistan presents an interesting case for the investigation of the CSR activities advocated by national and international organizations for a variety of important reasons. It is a country that is beset by multiple problems, like terrorism, industrial crises, lack of health and educational infrastructure, and political and economic instability. Moreover, business organizations operate in a context characterized by the production of poor-quality products, violations of human rights, substandard living conditions, labor problems such as wage rates, which do not allow a reasonable standard of living, and, most importantly, excessive child labor. Environmental and water pollution is another threat that is growing daily because of the way in which companies mismanage waste materials. Therefore, there is desperate need to study CSR in the context of Pakistan to raise the need, importance, and awareness level among both local public and regulatory bodies.

In the case of Pakistan, CSR is a new phenomenon that has emerged only 10 years ago. With reference to CSR disclosures, the SECP introduced the first Companies (Corporate Social Responsibility) General Order, 2009. According to this order, all listed companies are required to disclose information about their CSR activities that they have been performed in whole year. This is to be reported in the directors' report to the shareholders part of the annual reports of firms. SECP specified 12 headings under the umbrella of CSR. However, companies are not limited to only undertaking CSR activities and disclosing information in these areas. They can engage in different aspects of CSR activities according the interests of their stakeholders. In 2013, the SECP introduced the Corporate Social Responsibility Voluntary Guidelines to promote ethics in business and make corporations more accountable to stakeholders for their decisions. The SECP makes it mandatory for firms to provide a clearly defined CSR policy and vision, and to show their CSR commitment in terms of time and the allocation of resources and personnel, while integrating it into their overall corporate vision, code of ethics, and business plan. According to these guidelines, companies are encouraged to establish a 'CSR Consultative Committee' and a 'CSR Management System' to develop a comprehensive framework for CSR within the organization.

\section{Review of Existing Approaches to Measure CSR}

In the CSR literature, several approaches have been identified to measure CSR. However, most of the previous studies used four methods extensively in order to measure CSR, which are the disclosure method, reputational indices or scales, forced-choice questionnaire surveys, and single dimension-based measure.

\subsection{Social Ratings/Reputational Indices}

The first and most extensively used method to measure CSR is the use of social ratings based on various reputational indices compiled by various social agencies. The social agencies investigate the companies' CSR performance and rate them accordingly with respect to their various social, environmental, and other CSR-related activities. These agencies collect information about CSR activities through different sources, such as surveys and interviews from the various public respondents, knowledgeable observers, business professionals, company employees, the firm website, firm financial annual reports, and newspapers $[10,28]$. Some of the most widely used indices are 
Moskowitz's tripartite ratings, e.g., Reference [29], the Kinder, Lydenberg, Domini (KLD) index, e.g., References [30-32], the Domini Social Index (DSI) [33,34], and Fortune magazine's reputational ratings, e.g., Reference [35].

\subsection{Disclosure Method/Content Analysis}

The second broadly used approach to measure CSR is the disclosure method. It is "the process of communicating the social and environmental effects of an organization's economic action to particular interest grouping within society and to the society at large" (see Reference [36], p. 9). In this approach, content analysis is employed to measure CSR by converting the textual information about the firm's social activities published in various sources like financial annual reports, CSR reports, website, media, newspapers or magazines, and mail or letters to the shareholders into the quantitative scale to draw the inferences about the social performance of firms $[6,7,10]$.

\subsection{Questionnaire Survey}

A forced-choice questionnaire survey is the third approach that is used in the existing literature to measure CSR, in which researchers collect information about the firm's CSR activities through questionnaires or interviews from the company's employees, executives, or knowledgeable respondents. The Aupperle, Carroll [12] study was among the earliest studies that developed a forced-choice questionnaire using the Carroll [11] model of CSR. Similarly, Rettab, Brik [37] constructed a survey questionnaire to study the link between CSR and organisational performance. More recent studies, Gallardo-Vázquez and Sanchez-Hernandez [38] and Fatma, Rahman [39] also used this approach in order to build a CSR measurement scale.

\subsection{Single-Dimension-Based Measure of CSR}

The fourth approach is the use of single-dimension-based constructs of CSR, in which the focus is on any dimension of CSR, like environment protection, charitable donations, or research and development, e.g., References [13,40-43]. The use of a single-dimension-based construct of CSR is also problematic, as one dimension does not portray the breadth of the CSR concept. It is well accepted that CSR is a multidimensional construct [11] based on the social aspects of community, product, environment, customers, and so on. Therefore, studies that have used a single dimension lack validity because their findings are difficult to generalize [44,45].

The present research used two approaches to measure CSR. First, a disclosure approach, and second, a multidimensional financial approach. Why we used only two approaches is as follows. In the case of Pakistan, there is no social rating agency that rates the CSR practices of firms, which is why the social index/rating approach is not possible to exercise in this context. Moreover, the present research did not use the questionnaire approach either. Response bias is the potential drawback of this method that might exist at two levels, selection bias, and attitude bias. Selection bias is likely to appear because it is very much possible that socially responsible corporations respond actively in comparison to non- or less socially responsible firms [46]. Attitude bias might also exist, if respondents deliberately select those choices that show the desirable social behavior of the firm that actually does not exist in reality [47].

\section{Methodology}

The present study used two approaches to establish two separate measures of CSR, qualitative as well as quantitative, for in-depth analysis of CSR activities of Pakistani listed firms (see Figure 1). First is the disclosure approach and second is the multidimensional financial approach. 


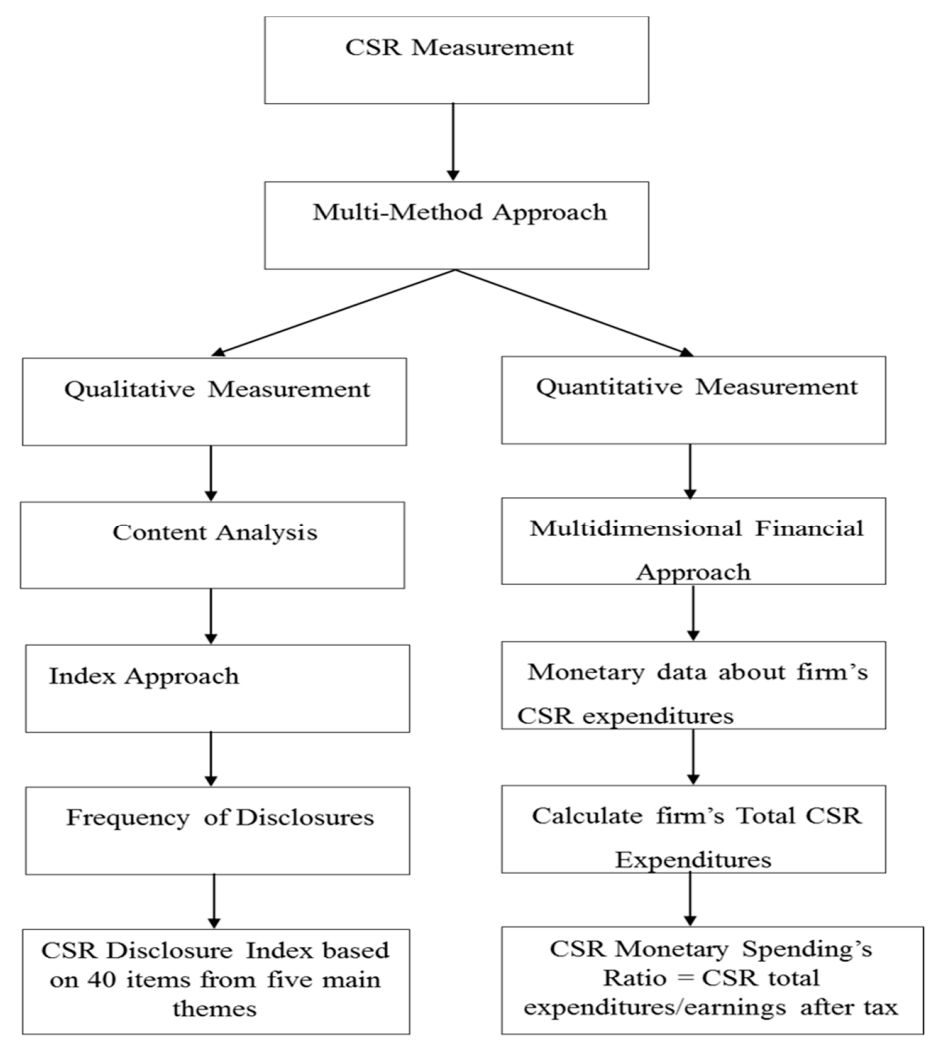

Figure 1. Framework of CSR Measurement (Source: author).

\subsection{Disclosure Approach}

Different researchers provide the different definitions of CSR disclosures. The current research follows Chan, Watson (Reference [48], p. 64) who define it as the information disclosed by a company in its annual report regarding the company's initiatives, programs, and application of the resources influencing the public in general and company's stakeholders in particular.

\subsubsection{Content Analysis (CA)}

CA is employed to measure the CSR disclosures. It is one of the most extensively used research methodology in the social research stream, particularly in CSR-related studies to measure the social and environmental performance of a company [49-51].

\subsubsection{Index or Volumetric Approach}

In the existing literature, there are two commonly used approaches of content analysis, one is the 'volumetric' approach, and the other one is 'index' approach. In the volumetric approach, researchers check the overall volume of a particular item of information in selected samples of text (like number of words, sentences, paragraph, or proportion of a particular page, like A4). Opposite this, in the 'index' approach, the presence or absence of a particular concept is checked by following a simple binary coding method (assign 1 for the presence of particular item and 0 for the absence) and then establishing an index based on the aggregated score of the overall selected items [52,53]. The present study used index approach; the focus of this study is to investigate the quality of CSR disclosures and determine the breadth of the firms' commitment towards their socially responsible behavior performance.

\subsubsection{Sampling Units}

The present study used annual reports of the firms as the sampling unit. There are several reasons for choosing annual reports as the stand-alone source of a company's CSR disclosure information. First, 
a large number of previous studies that investigated a firm's social and environmental performance used annual reports, and, consistent with these studies, we choose annual reports $[7,48,53]$. Second, annual reports are considered to be the primary source through which a company communicates its information with a wide range of stakeholders [5]. As stated by Van der Laan Smith, Adhikari (Reference [54], p. 136), "the use of the annual report as a method of communication with stakeholders is also consistent with the principles of stakeholder theory". Third, the annual report is considered one of the most comprehensive documents of the firm that summarizes the overall activities of the corporation around the year [55].

\subsubsection{Coding Units or Unit of Analysis}

The crucial demand for content analysis is the right identification of an appropriate unit of analysis that supports the specific research question of the study. Different researchers adopted different units of analysis; word counts [56-59], sentence counts [3,60,61], page proportions [55] and frequency of disclosure [27,50,62], and high/low disclosure ratings [63]. In this study, "frequency of disclosure" is employed as the unit of analysis for developing the CSR Disclosure Index (CSR Index). The prime focus of this research is to identify the presence or absence of information about a particular CSR activity performed by a firm in its annual report to explore the firm's commitment with the social uplift of the society. Moreover, this study is intended to establish a CSR Index that can be further used for empirical research.

\subsubsection{Development of Themes or Categories}

Another important and critical part of the content analysis is the right selection and combination of themes or categories into which the selected context units are classified accordingly. In order to develop the checklist of CSR-related activities (themes), this study first considered the Kinder, Lydenberg, and Domini (KLD) (1999) database. KLD is considered a benchmark while measuring CSR performance of the firm and most of the existing studies used it [31]. However, KLD is focused only on U.S.-listed firms, due to which there are certain CSR categories/themes that are specific to the U.S. economy. Therefore, apart from KLD, certain other studies are also considered that have been conducted in the context of both developed and developing economies on CSR disclosure in order to establish the CSR themes that are specific and relevant to the Pakistan business environment. Studies that have been done in the context of developed world [10,60], and studies conducted in the context of developing economies include References [3,64] and a Pakistani-context study [7,27].

Further, a detailed list of the studies is attached on the Appendix A, which is used to establish the CSR Index's main themes and subthemes. Finally, a checklist of 40 items is classified under five broad dimensions of CSR: general community welfare, health and education, environment and energy, product, customer and stakeholders and workforce-developed specifically with reference to Pakistani listed firms.

\subsubsection{CSR Disclosure Indices}

A CSR disclosure index is developed based on 40 items from the five main themes, general community welfare, health and education, environment and energy, product, and customer and stakeholders and workforce. CSRD Index $=\sum \mathrm{d}_{\mathrm{i}}{ }^{\mathrm{n}}{ }^{40} / \mathrm{n}_{\mathrm{j}}$. where, di is 1 , if the information about item $\mathrm{di}$ is revealed and 0 if otherwise. nj is the total number of items for jth firms $\mathrm{nj}=40$. Following a similar approach, five individual indices are also developed: (1) General Community Welfare index, which includes eleven items; (2) Health and Education, which includes five items; (3) Environment and Energy, based on seven items; (4) Product, Customer, and Stakeholders, based on nine items; and (5) Workforce index, based on eight items. 


\subsubsection{Reliability of the CSR Disclosure Index}

Following the previous studies that use disclosure approach to construct CSR or other voluntary disclosure indices [51,65-67], Cronbach's coefficient alpha [68] is used in order to assess the reliability of the CSR disclosure index, as well as the five individual indices. Table 1 shows the reliability of the overall CSR disclosure index of the current study and the five individual themes indices. The value of Cronbach's alpha for the CSR index containing 40 standardized items classified under five main themes is 0.924 , which is considered excellent in accepting that all the items in the disclosure index measure the same construct and there is less chance that random error reduces the power of empirical results using this CSR disclosure index.

Table 1. Reliability of overall Corporate Social Responsibility (CSR) index and the five subtheme indices.

\begin{tabular}{cccc}
\hline Sr. No & Industrial Sectors & Number of Items & Cronbach's Alpha \\
\hline 1 & CSR Index & 40 & 0.924 \\
2 & General Community Welfare & 11 & 0.783 \\
3 & Health and Education & 5 & 0.809 \\
4 & Environment and Energy & 7 & 0.817 \\
5 & Product, Customer and Stakeholders & 9 & 0.637 \\
6 & Workforce & 8 & 0.705 \\
& $N$ & 1360 & \\
\hline
\end{tabular}

\subsection{Multidimensional Financial Approach}

The second approach that is used to measure CSR is the multidimensional financial approach. In this approach, the firms' CSR monetary spending ratio (CSR-MSR) is calculated. For this purpose, financial data about firms' monetary expenditures in million PKR for the three dimensions of CSR - donations, employee welfare, and research and development-have been collected from their annual reports. After collecting the data on each dimension of CSR, the firm's total CSR expenditures are calculated by integrating all amounts spent in all three dimensions. Then, a firm's monetary spending ratio is calculated by dividing the firm's total CSR expenditure in these three dimensions to its earnings after tax amount following the studies of References $[40,41,69]$. The selection of these three dimensions is restricted based on their data availability in annual reports of companies listed in the Pakistan Stock Exchange (PSE).

\subsection{Sample and Population}

The initial total population of the present research is drawn from the manufacturing sector of Pakistan, from 17 industrial sectors, which include 304 firms listed on the PSE covering the time period from 2008 to 2015 for collecting CSR data. Further, in order to refine the data sample, certain filtering techniques were also applied. First, availability of complete annual reports for the complete selected period was the most important task. This is because the measurement of CSR is mainly based on the firms' disclosed information (qualitative and quantitative) about their CSR activities in their annual reports. Therefore, only those firms for which complete annual reports are available were selected. Second, the firms that remained operational for the complete selected duration and remained listed from 2006 to 2015. Third, only those firms that are not state-owned enterprises or public-utility firms were selected. Fourth, firms that did not merge during the selected period. After applying these filtering techniques, the final sample was based upon 170 manufacturing firms from the period 2008 to 2015, generating total cross-sectional observations from 1360 firm years. 


\section{Results and Discussion}

\subsection{Overall Analysis}

The descriptive results of CSR disclosure indices are reflected in Table 2. The mean score of the overall CSR disclosure index is 19.87 out of 40 indicating that on average sample firms disclosed their CSR activities on approximately 50\% selected parameters. With respect to the five individual indices, the average value of products and customer's index is 7.04, which is the highest amongst all others. It implies that CSR information regarding products and customers is mostly disclosed by the companies. This is due the fact that most of the companies in the selected sample are ISO 9000-certified, which is an international system of quality management and companies need to maintain a minimum level of cosmetic CSR activities in order to avoid compliance penalties. It requires the companies to effectively document and disclose information about the important elements of their product, process, quality system, and fulfillment of customer satisfaction. The second-highest category about which companies disclose more information is employee welfare that holds the mean value of 5.03 and a minimum value of 4 .

On the other hand, it is found that less information has been disclosed by the companies in the health and education dimension of CSR, with a mean score of 1.98. Although numerous health-related facilities and activities are being conducted by the business community of Pakistan, which is highlighted in electronic and print media, disclosure in the annual reports of companies is less. These results supported the fact that the Pakistani Government has focused less towards the development of education and health sector. According to the "Public Financing of Education in Pakistan and Agenda for Education Budget 2016-2017" report, Pakistan's financing or allocation of budget for the education sectors is lowest among South-Asian economies [70]. CSR disclosure for environment and energy is second last among all, with a mean score of 2.28. The disclosure of CSR information for community welfare is found to be moderate among all, with a respective mean score of 3.51 .

Table 2. Descriptive statistics for CSR disclosure indices.

\begin{tabular}{lcccccc}
\hline Industry & $\boldsymbol{N}$ & Mean & Median & Std. Devi & Minimum & Maximum \\
\hline CSRD Index & 1360 & 19.87 & 19 & 8.05 & 4 & 39 \\
Community Welfare & 1360 & 3.51 & 4 & 2.47 & 0 & 11 \\
Health and Education & 1360 & 1.98 & 2 & 1.78 & 0 & 5 \\
Environment and Energy & 1360 & 2.28 & 2 & 2.12 & 0 & 7 \\
Product and customer & 1360 & 7.04 & 7 & 1.53 & 3 & 9 \\
Workforce/Employees & 1360 & 5.03 & 5 & 1.86 & 4 & 8 \\
\hline
\end{tabular}

Table 3 reports the descriptive statistics about firms' monetary expenditures on their CSR activities in million PKR. Analysis shows that Pakistani firms spend the highest amount, i.e., 147 million PKR, on employee welfare. The plausible reason attributed towards this behavior of Pakistani companies may be due to the fact that monetary contribution towards Workers Welfare Fund for employees' benefits is required by WWF ordinance 1971. Moreover, employees play an important role in the value creation of a firm, as their experience, knowledge, skills, and capabilities enable the firm to create innovation and strategic regeneration [71,72]. Therefore, firms consider spending on employees as an investment that pays them back in the future. This finding is consistent with the findings of the Khan [53] and Sharif and Rashid [27] studies and supports the argument that firms in developing countries are more inclined towards employee-welfare-related CSR activities and, therefore, disclose more information about them. On the lower side, these industries spent 14 million PKR and 9 million PKR on research and development (R and $\mathrm{D}$ ) and charitable donations, respectively. Other statistics have also been reported in the Table 3. 
Table 3. Descriptive statistics of monetary CSR spending in million PKR.

\begin{tabular}{lcccccc}
\hline \multicolumn{1}{c}{ Industry } & $\boldsymbol{N}$ & Mean & Median & Std. Devi & Minimum & Maximum \\
\hline Total CSR Spending & 1360 & 170 & 34 & 446 & 0 & 4852 \\
Charitable Donations' & 1360 & 9 & 7.1 & 30 & 0 & 446 \\
Employee Welfare & 1360 & 147 & 30 & 396 & 0 & 4750 \\
R and D & 1360 & 14 & 0 & 95 & 0 & 1648 \\
\hline
\end{tabular}

\subsection{Industry-Wise Analysis}

The current research also analyzed industry-wise CSR disclosures. A comparison has been made using one-way ANOVA to reflect the industries on the basis of their CSR spending and the results are reported in Table 4. It is noted that the mean of CSR disclosure of the oil and gas industry is 29.93, highest among all others. It implies that oil and gas industry share the highest amount of CSR information than other industries. Further, other industries that share a greater amount of their CSR practices information are cable and electrical goods, with an average of 23.03 , followed by cement, with a mean value of 21.60 , power generation and distribution, with the mean of 21.33, and automobile parts and assemblers with the mean value of 21.18.

Table 4. Industry-wise analysis of CSR disclosures-one-way ANOVA.

\begin{tabular}{|c|c|c|c|c|c|c|}
\hline Industry & $N$ & Mean & Std. Devi & Std. Error & Minimum & Maximum \\
\hline Automobile & 136 & 21.18 & 8.201 & 0.703 & 8 & 34 \\
\hline Cable and Electrical Goods & 32 & 23.03 & 5.427 & 0.959 & 14 & 34 \\
\hline Cement & 120 & 21.60 & 8.847 & 0.808 & 8 & 37 \\
\hline Engineering & 72 & 19.99 & 4.983 & 0.587 & 8 & 28 \\
\hline Food and Personal Care Products & 112 & 18.97 & 8.606 & 0.813 & 6 & 34 \\
\hline Paper and Board & 40 & 15.75 & 4.337 & 0.686 & 9 & 24 \\
\hline Pharmaceutical & 48 & 19.33 & 5.617 & 0.811 & 8 & 30 \\
\hline Power Generation and Distribution & 48 & 21.33 & 6.720 & 0.970 & 10 & 35 \\
\hline Sugar and Allied Industries & 184 & 17.29 & 6.043 & 0.445 & 7 & 35 \\
\hline Technology and Telecommunication & 48 & 18.90 & 7.572 & 1.093 & 4 & 35 \\
\hline
\end{tabular}

The level of statistical significance is represented by ${ }^{*},{ }^{* *},{ }^{* *}$ at $10 \%, 5 \%$, and $1 \%$, respectively.

The reason for higher CSR disclosures in these industries is obvious, as they hold the major capitalization of sectors of the Pakistan Stock Exchange, so they have more resources for practising CSR activities and reporting them efficiently in their annual reports. Moreover, during recent years, the decrease in fuel prices has increased the demand for automobiles and, in turn, oil and gas. Similarly, the increase in level of construction activities in the country has increased the demand for cement. This state of affairs has made these industries operate at optimal levels and generate high profits. Due to higher profits and the fact that these industries adversely affect the natural environment during production, CSR has increased.

On the other hand, the mean score of CSR disclosure of the glass and ceramic industry is 11.65 , lowest than all others. This indicates that the glass and ceramic industry discloses the least amount of information than all other industries.

The present study has also analyzed CSR monetary spending across different industrial sectors of Pakistan. Table 5 reflects the mean score (amount of spending in million PKR) of each industry given against it. It is reported that the oil and gas industry was again on top in spending in CSR activities. It spent 871.89 million PKR on average in various CSR practices, which is the highest amount among those of other industries. Contrary to that, the glass and ceramics industries spent the least amount (22.33 million PKR) on CSR relative to other industries. As the $p$-value of the analysis of variance is less 
than 0.01 , it is inferred that the respective CSR spending of these industries is significantly different from each other.

Table 5. Industry-wise analysis of monetary CSR spending in million PKR-one-way ANOVA.

\begin{tabular}{|c|c|c|c|c|c|c|}
\hline Industry & $N$ & Mean & Std. Devi & Std. Error & Minimum & Maximum \\
\hline Automobile & 1280 & 127.74 & 153.77 & 13.18 & 1 & 733 \\
\hline Cable and Electrical Goods & 32 & 59.96 & 61.81 & 10.92 & 4 & 209 \\
\hline Cement & 120 & 142.40 & 227.07 & 20.72 & 0 & 1557 \\
\hline Engineering & 72 & 26.62 & 39.87 & 4.69 & 1 & 164 \\
\hline Food and Personal Care Products & 112 & 137.55 & 277.86 & 26.25 & 1 & 1458 \\
\hline Paper and Board & 40 & 54.15 & 84.13 & 13.30 & 0 & 379 \\
\hline Pharmaceutical & 48 & 208.77 & 231.42 & 33.40 & 16 & 853 \\
\hline Power Generation and Distribution & 48 & 297.56 & 384.92 & 55.55 & 1 & 1915 \\
\hline Sugar and Allied Industries & 184 & 22.33 & 25.55 & 1.88 & 0 & 126 \\
\hline Technology and Telecommunication & 48 & 238.12 & 318.78 & 46.01 & 2 & 1075 \\
\hline
\end{tabular}

The level of statistical significance is represented by ${ }^{*}, * *, * * *$ at $10 \%, 5 \%$ and $1 \%$, respectively.

\subsection{Year-Wise Analysis}

One-way ANOVA has also been applied to analyze the year-wise variance among CSR disclosures ranging from 2008 to 2015. Table 6 reports that the mean score of CSR disclosure in 2015 is highest than that in the previous seven years. On the other hand, CSR disclosure is lowest in 2008, with a mean score of 17.04. This also reflects an interesting finding: that the disclosure of CSR information is increasing every year. These results highlight the increasing importance of CSR over the years, due to which firms are continuously improving their CSR framework, integrating CSR strategies in their system, and communicating them with their stakeholders. Analysis of variance reports an F-value of 9.11, with the $p$-value less than 0.01 , indicating that there is significant difference among the amount of CSR information being disclosed from 2008 to 2015.

Table 6. Year-wise analysis of CSR disclosures-One-way ANOVA.

\begin{tabular}{|c|c|c|c|c|c|c|}
\hline Year & $N$ & Mean & Std. Devi & Std. Error & Minimum & Maximum \\
\hline 2008 & 170 & 17.04 & 7.920 & 0.607 & 4 & 35 \\
\hline 2009 & 170 & 17.86 & 8.161 & 0.626 & 6 & 36 \\
\hline 2010 & 170 & 18.92 & 8.039 & 0.617 & 6 & 36 \\
\hline 2011 & 170 & 19.51 & 7.797 & 0.598 & 6 & 38 \\
\hline 2012 & 170 & 20.22 & 7.986 & 0.613 & 6 & 38 \\
\hline 2013 & 170 & 21.21 & 7.525 & 0.577 & 7 & 39 \\
\hline 2014 & 170 & 21.69 & 7.864 & 0.603 & 7 & 37 \\
\hline 2015 & 170 & 22.15 & 7.983 & 0.612 & 7 & 39 \\
\hline Total & 1360 & 19.82 & 8.075 & 0.219 & 4 & 39 \\
\hline F-Value & $9.11^{* * *}$ & & & & & \\
\hline
\end{tabular}

Table 7 reports the year-wise analysis of the variance of firms' CSR monetary spending from 2008 to 2015. Similar to the CSR information disclosure, the highest amount, i.e., 236.86 million PKR, was spent in 2015 than in previous years. The lowest amount, i.e., 107.74 million PKR, spent on CSR was in 2008. The amount spent on CSR per year has also been increasing every year from 2008 to 2015. The $p$-value of analysis of variance is 0.05 , indicating that there is significant difference between per year amount spent on CSR. 
Table 7. Year-wise analysis of monetary CSR spending-One-way ANOVA.

\begin{tabular}{ccccccc}
\hline Year & $\boldsymbol{N}$ & Mean & Std. Devi & Std. Error & Minimum & Maximum \\
\hline 2008 & 170 & 107.74 & 258.007 & 19.788 & 0 & 2090 \\
2009 & 170 & 108.36 & 283.891 & 21.773 & 0 & 2818 \\
2010 & 170 & 136.64 & 319.431 & 24.499 & 0 & 2693 \\
2011 & 170 & 180.32 & 469.193 & 35.985 & 0 & 3530 \\
2012 & 170 & 175.34 & 491.569 & 37.702 & 0 & 4326 \\
2013 & 170 & 191.85 & 495.275 & 37.986 & 0 & 4214 \\
2014 & 170 & 225.48 & 587.401 & 45.052 & 0 & 4852 \\
2015 & 170 & 236.86 & 531.222 & 40.743 & 0 & 3380 \\
Total & 1360 & 170.33 & 446.139 & 12.098 & 0 & 4852 \\
F-Value & $2.07 * *$ & & &
\end{tabular}

Year-wise analysis reveals that firms' commitment to CSR practices and the extent of their disclosures have increased with the passage of time. Several other studies in developing countries have also found the same increasing trend of CSR and its disclosures [3,73]. These findings are also consistent with the findings of Malik and Kanwal [7], who also reported that CSR disclosures increased tremendously from 18 to $52 \%$ from 2008 to 2014 in the case of the pharmaceutical industry of Pakistan. However, this increase is linked to the increase in various coercive external pressures from powerful external forces/stakeholders, such as foreign investors, introduction of ISO systems, international media, etc. $[19,22]$, rather than internal pressures from the local public, institutions, and regulatory bodies $[4,6,20,25]$.

\subsection{Effect of SECP Reforms on CSR Disclosures of Firms}

Moreover, this study also analyzed the effect of various CSR-related governmental reforms on the CSR performance of firms. Table 8 shows the results of the effect of CSR General Order, 2009, issued by SECP on the intensity of firms' CSR disclosures. Independent sample $t$-test has been applied to analyze the difference in CSR disclosure before and after CSR General Order 2009. The upper panel of Table 8 provides a mean comparison for 2008 and 2010, and the lower panel provides the mean comparison for 2008 and 2011 with respect to the CSR disclosures. The mean of CSR disclosure in 2008 is 17.04, which increased up to 18.92 in 2010 after CSR General Order 2009. The disclosure of CSR information has further increased, up to 19.51 in 2011. This year, increase is significant, as the $p$-value of the $t$-test was less than 0.05 for the 2008-2010 comparison, and 0.01 for 2008-2011 comparison. These findings indicate that CSR disclosure has significantly increased after SECP 2009's CSR General Order.

Table 8. Effect of SECP CSR General Order 2009 (one sample $t$-test).

\begin{tabular}{ccccc}
\hline Sector & $N$ & Mean & Std. Devi & Std. Error \\
\hline 2008 & 170 & 17.04 & 7.920 & 0.607 \\
2010 & 170 & 18.92 & 8.039 & 0.617 \\
Mean Difference & -1.82 & & & \\
$t$-value & $-2.175^{* *}$ & & & \\
2008 & 170 & 17.04 & 7.920 & 0.607 \\
2011 & 170 & 19.51 & 7.797 & 0.598 \\
Mean Difference & -2.475 & & & \\
$t$-value & $-2.905^{* * *}$ & & & \\
\hline The level of statistical significance is represented by ******at $10 \%, 5 \%$, and $1 \%$, respectively.
\end{tabular}

The level of statistical significance is represented by $*, * *, * * *$ at $10 \%, 5 \%$, and $1 \%$, respectively.

Similarly, SECP's CSR Voluntary Order has been enacted in 2013. To check the difference between CSR disclosure by the companies before and after this ordinance, an independent sample $t$-test has been applied. Results are reported in Table 9, which shows that that there is significant difference between CSR disclosure in 2012 and that in 2014 (an increase of 1.47) as p-value of the test is less than 0.1. Similarly, CSR disclosures have increased by 1.93 in 2015 . The increase is also significant 
as its $p$-value is less than 0.05 . It can thus be inferred that such an ordinance significantly promotes awareness in Pakistani listed firms regarding their CSR and its disclosure in their reports.

Table 9. Effect of SECP CSR Voluntary Order 2013 (one sample $t$-test).

\begin{tabular}{ccccc}
\hline Sector & $N$ & Mean & Std. Devi & Std. Error \\
\hline 2012 & 170 & 20.22 & 7.986 & 0.613 \\
2014 & 170 & 21.69 & 7.864 & 0.603 \\
Mean Difference & -1.471 & & & \\
$t$-value & $-1.711^{*}$ & & & \\
2012 & 170 & 20.22 & 7.986 & 0.613 \\
2015 & 170 & 22.15 & 7.983 & 0.612 \\
Mean Difference & -1.929 & & & \\
$t$-value & $-2.228^{* *}$ & & & \\
\hline
\end{tabular}

The level of statistical significance is represented by $*{ }^{* *},{ }^{* * *}$ at $10 \%, 5 \%$, and $1 \%$, respectively.

\section{Conclusions}

Keeping in view the aforementioned gap in the literature on CSR in developing countries, the present study aims to contribute in the literature of CSR on developing countries by increasing the understanding about CSR practices and their disclosures using the case of Pakistan.

There are two primary objectives of this study. The first objective was to develop a comprehensive framework for CSR measurement for assessing and examining CSR practices of Pakistani listed forms. For this purpose, a multimethod approach has been adopted to measure CSR practices, both quantitatively and qualitatively, for a large dataset of 170 listed firms for eight years, from 2008 to 2015. Content analysis was employed to establish a statistically tested CSR disclosure index and five other social indices based on five themes of CSR: community welfare, health and education, environment and energy, product, and customer and workforce. Moreover, a CSR monetary spending ratio was established by dividing the firm's total CSR monetary expenditure to its net income after tax. The second main objective was to explore the various aspects of CSR practices of Pakistani firms, the extent of their disclosures, and their reporting trends.

Qualitative as well as quantitative results revealed that, although CSR practices and their disclosures are voluntary in Pakistan, the commitment of Pakistani firms to CSR is still quite good. On average, Pakistani firms spent 170 million PKR in performing various CSR activities and disclosed $50 \%$ of the information on selected CSR items. These findings hold special importance in the studied context of developing economies, as it corresponds to the conjecture that CSR is gaining increased importance in developing countries.

With respect to the individual five themes of CSR, disclosures in product and customers are highest amongst all other. This is due to the fact that most of the companies in the selected sample are ISO 9000-certified, which is an international system of quality management and companies need to maintain a minimum level of cosmetic CSR activities in order to avoid compliance penalties. On the other hand, it is found that the least amount of information has been disclosed by the companies in the health and education dimension of CSR, with a mean score of 1.98. These results supported the fact that the Pakistani Government has focused less towards the development of the education and health sectors.

The industry-wise analysis of CSR practices concluded that substantial variations exist across different industries in terms of both CSR disclosures and monetary giving. The oil and gas industry was found to be most responsible among all industries, disclosing more information about their CSR activities and spending more money on these activities. Contrary to that, the glass and ceramics industries spent the least amount (22.33 million PKR) on CSR and reported less information about them.

The year-wise analysis reflected an interesting finding: that firms' CSR disclosures and monetary spending are increasing every year. These results are attributed to the phenomenon that there is continuous increase in the importance of CSR over the years, not only in developed economies but 
also in developing economies, due to which firms are continuously improving their CSR framework, integrating CSR strategies in their system, and communicating them with their stakeholders.

Moreover, results of this also support the positive and significant effect of CSR-related SECP reforms on the CSR performance of firms. These findings are consistent with the notion that the institutional environment and infrastructure of a country powerfully influence firms to follow CSR practices.

The findings of this study offer important implications for a range of stakeholders, like policymakers/regulators, corporate strategy formulators, and investors.

First of all, this study provides a comprehensive framework for measuring the CSR performance of Pakistani listed firms. This should help policymakers to introduce an effective CSR reporting system to evaluate the corporate social performance of Pakistani listed firms. Moreover, results of this study highlight that there is a strong and positive effect of SECP CSR General Order 2009 and SECP CSR Voluntary Order 2013. However, these orders require Pakistani listed firms to disclose information about their CSR activities on a voluntary basis, due to which a comprehensive framework for CSR disclosures is still lacking in Pakistan. Therefore, SECP should introduce a mandatory framework for CSR disclosures and the social auditing of firms to promote CSR in Pakistan. Moreover, findings of this study highlight that firms are paying less attention towards health and education. Therefore, policymakers should focus more on improving the health and education systems and introduce such policies that encourage business organizations to focus on health and education-related CSR activities along with the others. Managers can also use the findings of this research to formulate and implement CSR policies, which effectively help them to establish good relations with different stakeholders, because it has been proven by many previous studies that the value of an organization can increase when managers undertake effective CSR initiatives in order to establish long-lasting positive relationships with stakeholders. Moreover, investors and shareholders are very important to firms, as they are the ones who provide the capital for carrying various business operations and investment projects, so they can play the key role in firm's commitment towards CSR. Therefore, investors from Pakistan should carefully make their decisions while investing in a firm and support their socially responsible behavior. Most importantly, this study helps future researchers to empirically investigate the different aspects of CSR research and, thus, help in enhancing CSR research in developing economies. This is the first kind of empirical study on its own that developed a comprehensive scale for the measurement of CSR in developing economies, and it can help future studies to empirically investigate the different aspects of CSR research and draw sound inferences.

As with all research, this study has certain limitations as well as offering new insights for future research avenues. Firstly, it has drawn only on the annual financial reports of firms as a source of information about their CSR activities, despite the fact that management can also use other modes of mass communication, such as newspapers, inhouse magazines, and the Internet for disclosing such details. Further studies can also consider these communication channels to form a picture of firms' commitment to CSR. Secondly, the lack of availability of data has limited the sample analyzed to just 170 Pakistani nonfinancial firms over a period of eight years. Future research should bear such concerns in mind and seek to present a basis for more generalized results by collecting more data across other industrial and financial sectors. Furthermore, in order to arrive at stronger conclusions, future studies should also analyze firms from other countries with similar economies to Pakistan, particularly in south Asia.

Author Contributions: S.E., M.S.N., S.T., and Q.R.K. equally contributed to the paper, wrote the paper, collected the data, and analyzed them. I.A. helped in providing ideas and preparing the model. M.N. reviewed and revised the paper.

Funding: This research project received no funding.

Conflicts of Interest: The authors declare no conflict of interest. 


\section{Appendix A}

Table A1. Checklist of CSR disclosure themes/items.

\section{1: Community Welfare}

1.1 Acknowledgement of corporate social responsibility

1.2 Disclosures about corporate objectives or policies for corporate social responsibility

1.3 Donations for flood-affected people

1.4 Donations for earthquake-affected people

1.5 Donations for internally displaced people (IDPs), victims of war or terrorism activities

1.6 Donations by employees for affected people

1.7 Rural development programs (less developed/remote areas/underprivileged)

1.8 Women's empowerment and development program

1.9 Sponsoring and donations to various sports activities, national and international games and events

1.10 Assistance to different trusts that works for destitute or disabled people of society

1.11 Other general community welfare activities/poverty alleviation

\section{2: Contribution to Education and Health Sector}

2.1 Donation to different schools, colleges, and universities for educational facilities

2.2 Scholarships to meritorious and poor students

2.3 Sponsoring or organizing different educational activities or events at local and international level

2.4 Provision of healthcare services (facilitating/supporting health sector)

2.5 Sponsoring or donations for different hospitals to run their operations (donation of funds for running cancer hospitals, donation to eye hospitals, donation of cash money for supporting various operations of kidney hospitals)

\section{3: Environmental and Energy Importance}

3.1 Environmental protection/improvement/betterment or awareness

3.2 Pollution prevention or carbon emission control

3.3 Waste management or reuse of byproducts/minimized water consumption

3.4 Implantation of trees to make the country green, green office project

3.5 Energy efficiency, conservation, reduced energy consumption or energy reduction

3.6 Using, marketing, or producing renewable energy or green energy/utilizing waste materials or other sources for energy production

3.7 Investment in energy projects to overcome the country energy crisis (financing by different banks or FI).

\section{4: Product/Services and Customers}

4.1 Explanation of major kinds of product/services

4.2 Product or service quality, quality-control system, measures, or procedures

4.3 Product or service, equipment and plant or technology innovation, development or improvement ( $R$ and D)

4.4 Product or production process safety

4.5 Value added statement

4.6 Statement of ethics and business practices or code of ethics/statement of internal control

4.7 Stakeholder approach

4.8 Risk management committee/practices

4.9 Disclosing information about customer service or customer relationship

5: Workforce

5.1 Employee training, number of employees trained, training cost

5.2 Number of employees

5.3 Career-development programs

5.4 Employee benefits (retirement, medical, stock option schemes, loans, recreational, helping the employees to improve their education)

5.5 Staff-engagement programs or employee satisfaction/job sustainability

5.6 Compensation plan or policy for employees

5.7 Providing a safe, harmonious, and challenging working environment for the employee (security charges)

5.8 Employment of women, special persons, and minorities 


\section{References}

1. Wang, H.; Tong, L.; Takeuchi, R.; George, G. Corporate Social Responsibility: An overview and new research directions thematic issue on Corporate Social Responsibility. Acad. Manag. J. 2016, 59, 534-544. [CrossRef]

2. Jamali, D. A stakeholder approach to corporate social responsibility: A fresh perspective into theory and practice. J. Bus. Ethics 2008, 82, 213-231. [CrossRef]

3. Yusoff, H.; Mohamad, S.S.; Darus, F. The influence of CSR disclosure structure on corporate financial performance: Evidence from stakeholders' perspectives. Procedia Econ. Financ. 2013, 7, 213-220. [CrossRef]

4. Herbas Torrico, B.; Frank, B.; Arandia Tavera, C. Corporate Social Responsibility in Bolivia: Meanings and consequences. Int. J. Corp. Soc. Responsib. 2018, 3, 1-13. [CrossRef]

5. Rahman Belal, A. A study of corporate social disclosures in Bangladesh. Manag. Audit. J. 2001, 16, $274-289$. [CrossRef]

6. Kennedy Nyahunzvi, D. CSR reporting among Zimbabwe's hotel groups: A content analysis. Int. J. Contemp. Hosp. Manag. 2013, 25, 595-613. [CrossRef]

7. Malik, M.S.; Kanwal, L. Impact of Corporate Social Responsibility sisclosure on financial performance: Case study of listed pharmaceutical firms of Pakistan. J. Bus. Ethics 2018, 150, 69-78. [CrossRef]

8. Pisani, N.; Kourula, A.; Kolk, A.; Meijer, R. How global is international CSR research? Insights and recommendations from a systematic review. J. World Bus. 2017, 52, 591-614. [CrossRef]

9. Kates, R.W.; Parris, T.M.; Leiserowitz, A.A. What is sustainable development? Goals, indicators, values, and practice. Environment (Washington DC) 2005, 47, 8-21.

10. Abbott, W.F.; Monsen, R.J. On the measurement of corporate social responsibility: Self-reported disclosures as a method of measuring corporate social involvement. Acad. Manag. J. 1979, 22, 501-515.

11. Carroll, A.B. A three-dimensional conceptual model of corporate performance. Acad. Manag. Rev. 1979, 4, 497-505. [CrossRef]

12. Aupperle, K.E.; Carroll, A.B.; Hatfield, J.D. An empirical examination of the relationship between corporate social responsibility and profitability. Acad. Manag. J. 1985, 28, 446-463.

13. Bushee, B.J. The influence of institutional investors on myopic R\&D investment behavior. Account. Rev. 1998, 73, 305-333.

14. Turker, D. Measuring corporate social responsibility: A scale development study. J. Bus. Ethics 2009, 85, 411-427. [CrossRef]

15. Margolis, J.D.; Walsh, J.P. Misery loves companies: Rethinking social initiatives by business. Adm. Sci. Q. 2003, 48, 268-305. [CrossRef]

16. Tilt, C.A. Corporate social responsibility research: The importance of context. Int. J. Corp. Soc. Responsib. 2016, 1, 2. [CrossRef]

17. Athanasopoulou, A.; Selsky, J.W. The social context of corporate social responsibility: Enriching research with multiple perspectives and multiple levels. Bus. Soc. 2015, 54, 322-364. [CrossRef]

18. Badulescu, A.; Badulescu, D.; Saveanu, T.; Hatos, R. The relationship between firm size and age, and its social responsibility actions-Focus on a developing country (Romania). Sustainability 2018, 10, 805. [CrossRef]

19. Ali, W.; Frynas, J.G. The role of normative CSR-Promoting institutions in stimulating CSR disclosures in developing countries. Corp. Soc. Responsib. Environ. Manag. 2018, 25, 373-390. [CrossRef]

20. Ali, W.; Frynas, J.G.; Mahmood, Z. Determinants of corporate social responsibility (CSR) disclosure in developed and developing countries: A literature review. Corp. Soc. Responsib. Environ. Manag. 2017, 24, 273-294. [CrossRef]

21. Tilt, C.A. Making social and environmental accounting research relevant in developing countries: A matter of context? Soc. Environ. Account. J. 2018, 38, 145-150. [CrossRef]

22. Momin, M.A.; Parker, L.D. Motivations for corporate social responsibility reporting by MNC subsidiaries in an emerging country: The case of Bangladesh. Br. Account. Rev. 2013, 45, 215-228. [CrossRef]

23. Scholtens, B.; Kang, F.C. Corporate social responsibility and earnings management: Evidence from Asian economies. Corp. Soc. Responsib. Environ. Manag. 2013, 20, 95-112. [CrossRef] 
24. Runhaar, H.; Lafferty, H. Governing corporate social responsibility: An assessment of the contribution of the UN Global Compact to CSR strategies in the telecommunications industry. J. Bus. Ethics 2009, 84, 479-495. [CrossRef]

25. Belal, A.R.; Cooper, S. The absence of corporate social responsibility reporting in Bangladesh. Crit. Perspect. Account. 2011, 22, 654-667. [CrossRef]

26. Mian, S.N. Corporate social disclosure in Pakistan: A case study of fertilizers industry. J. Commer. 2010, 2, 1.

27. Sharif, M.; Rashid, K. Corporate governance and corporate social responsibility (CSR) reporting: An empirical evidence from commercial banks (CB) of Pakistan. Qual. Quant. 2014, 48, 2501-2521. [CrossRef]

28. Orlitzky, M.; Schmidt, F.L.; Rynes, S.L. Corporate social and financial performance: A meta-analysis. Organ. Stud. 2003, 24, 403-441. [CrossRef]

29. Cochran, P.L.; Wood, R.A. Corporate social responsibility and financial performance. Acad. Manag. J. 1984, 27, 42-56. [CrossRef]

30. Gao, L.; Zhang, J.H. Firms' earnings smoothing, corporate social responsibility, and valuation. J. Corp. Financ. 2015, 32, 108-127. [CrossRef]

31. Scholtens, B. A note on the interaction between corporate social responsibility and financial performance. Ecol. Econ. 2008, 68, 46-55. [CrossRef]

32. Heltzer, $\mathrm{W}$. The asymmetric relationship between corporate environmental responsibility and earnings management: Evidence from the United States. Manag. Audit. J. 2011, 26, 65-88. [CrossRef]

33. Michelon, G.; Boesso, G.; Kumar, K. Examining the link between strategic corporate social responsibility and company performance: An analysis of the best corporate citizens. Corp. Soc. Responsib. Environ. Manag. 2013, 20, 81-94. [CrossRef]

34. Becchetti, L.; Ciciretti, R.; Hasan, I.; Kobeissi, N. Corporate social responsibility and shareholder's value. J. Bus. Res. 2012, 65, 1628-1635. [CrossRef]

35. Basdeo, D.K.; Smith, K.G.; Grimm, C.M.; Rindova, V.P.; Derfus, P.J. The impact of market actions on firm reputation. Strat. Manag. J. 2006, 27, 1205-1219. [CrossRef]

36. Gray, R.; Owen, D.; Maunders, K. Corporate Social Reporting: Accounting and Accountability; Prentice-Hall International: Upper Saddle River, NJ, USA, 1987.

37. Rettab, B.; Brik, A.B.; Mellahi, K. A study of management perceptions of the impact of corporate social responsibility on organisational performance in emerging economies: The case of Dubai. J. Bus. Ethics 2009, 89, 371-390. [CrossRef]

38. Gallardo-Vázquez, D.; Sanchez-Hernandez, M.I. Measuring Corporate Social Responsibility for competitive success at a regional level. J. Clean. Prod. 2014, 72, 14-22. [CrossRef]

39. Fatma, M.; Rahman, Z.; Khan, I. Multi-item stakeholder based scale to measure CSR in the banking industry. Int. Strat. Manag. Rev. 2014, 2, 9-20. [CrossRef]

40. Pyo, G.; Lee, H.-Y. The association between corporate social responsibility activities and earnings quality: Evidence from donations and voluntary issuance of CSR reports. J. Appl. Bus. Res. (JABR) 2013, 29, 945-962. [CrossRef]

41. Lin, C.-H.; Yang, H.-L.; Liou, D.-Y. The impact of corporate social responsibility on financial performance: Evidence from business in Taiwan. Technol. Soc. 2009, 31, 56-63. [CrossRef]

42. Peng, C.-W.; Yang, M.-L. The effect of corporate social performance on financial performance: The moderating effect of ownership concentration. J. Bus. Ethics 2014, 123, 171-182. [CrossRef]

43. Cadez, S.; Guilding, C. Examining distinct carbon cost structures and climate change abatement strategies in $\mathrm{CO}_{2}$ polluting firms. Account. Audit. Account. J. 2017, 30, 1041-1064. [CrossRef]

44. Galant, A.; Cadez, S. Corporate social responsibility and financial performance relationship: A review of measurement approaches. Econ. Res.-Ekonomska Istraživanja 2017, 30, 676-693. [CrossRef]

45. Rowley, T.; Berman, S. A brand new brand of corporate social performance. Bus. Soc. 2000, 39, $397-418$. [CrossRef]

46. Cadez, S.; Czerny, A. Climate change mitigation strategies in carbon-intensive firms. J. Clean. Prod. 2016, 112, 4132-4143. [CrossRef]

47. Epstein, M.J.; Buhovac, A.R. Making Sustainability Work: Best Practices in Managing and Measuring Corporate Social, Environmental, and Economic Impacts; Berrett-Koehler Publishers: Oakland, CA, USA, 2014. 
48. Chan, M.C.; Watson, J.; Woodliff, D. Corporate governance quality and CSR disclosures. J. Bus. Ethics 2014, 125, 59-73. [CrossRef]

49. Akin, A.; Yilmaz, İ. Drivers of corporate social responsibility disclosures: Evidence from Turkish banking sector. Procedia Econ. Financ. 2016, 38, 2-7. [CrossRef]

50. Braam, G.J.; de Weerd, L.U.; Hauck, M.; Huijbregts, M.A. Determinants of corporate environmental reporting: The importance of environmental performance and assurance. J. Clean. Prod. 2016, 129, 724-734. [CrossRef]

51. Kansal, M.; Joshi, M.; Batra, G.S. Determinants of corporate social responsibility disclosures: Evidence from India. Adv. Account. 2014, 30, 217-229. [CrossRef]

52. Bebbington, J.; Larrinaga, C.; Moneva, J.M. Corporate social reporting and reputation risk management. Account. Audit. Account. J. 2008, 21, 337-361. [CrossRef]

53. Khan, H.-U.-Z. The effect of corporate governance elements on corporate social responsibility (CSR) reporting: Empirical evidence from private commercial banks of Bangladesh. Int. J. Law Manag. 2010, 52, 82-109. [CrossRef]

54. Van der Laan Smith, J.; Adhikari, A.; Tondkar, R.H. Exploring differences in social disclosures internationally: A stakeholder perspective. J. Account. Public Policy 2005, 24, 123-151. [CrossRef]

55. Deegan, C.; Rankin, M. Do Australian companies report environmental news objectively? An analysis of environmental disclosures by firms prosecuted successfully by the Environmental Protection Authority. Account. Audit. Account. J. 1996, 9, 50-67. [CrossRef]

56. Kamal, Y.; Deegan, C. Corporate social and environment-related governance disclosure practices in the textile and garment industry: Evidence from a developing country. Aust. Account. Rev. 2013, 23, 117-134. [CrossRef]

57. Bonsón, E.; Bednárová, M. CSR reporting practices of Eurozone companies. Revista de Contabilidad 2015, 18, 182-193. [CrossRef]

58. Azizul Islam, M.; Deegan, C. Motivations for an organisation within a developing country to report social responsibility information: Evidence from Bangladesh. Account. Audit. Account. J. 2008, 21, 850-874. [CrossRef]

59. Aribi, Z.A.; Gao, S. Corporate social responsibility disclosure: A comparison between islamic and conventional financial institutions. J. Financ. Rep. Account. 2010, 8, 72-91. [CrossRef]

60. Hackston, D.; Milne, M.J. Some determinants of social and environmental disclosures in New Zealand companies. Account. Audit. Account. J. 1996, 9, 77-108. [CrossRef]

61. Michelon, G.; Pilonato, S.; Ricceri, F. CSR reporting practices and the quality of disclosure: An empirical analysis. Crit. Perspect. Account. 2015, 33, 59-78. [CrossRef]

62. Haque, S.; Deegan, C. Corporate climate change-related governance practices and related disclosures: Evidence from Australia. Aust. Account. Rev. 2010, 20, 317-333. [CrossRef]

63. Patten, D.M. Exposure, legitimacy, and social disclosure. J. Account. Public Policy 1991, 10, 297-308. [CrossRef]

64. Khan, A.; Muttakin, M.B.; Siddiqui, J. Corporate governance and corporate social responsibility disclosures: Evidence from an emerging economy. J. Bus. Ethics 2013, 114, 207-223. [CrossRef]

65. Muttakin, M.B.; Khan, A. Determinants of corporate social disclosure: Empirical evidence from Bangladesh. Adv. Account. 2014, 30, 168-175. [CrossRef]

66. Gul, F.A.; Leung, S. Board leadership, outside directors' expertise and voluntary corporate disclosures. J. Account. Public Policy 2004, 23, 351-379. [CrossRef]

67. Botosan, C.A. Disclosure level and the cost of equity capital. Account. Rev. 1997, 40, 323-349.

68. Cronbach, L.J. Coefficient alpha and the internal structure of tests. Psychometrika 1951, 16, 297-334. [CrossRef]

69. Ehsan, S.; Kaleem, A. An empirical investigation of the relationship between corporate social responsibility and financial performance (Evidence from manufacturing sector of Pakistan). J. Basic Appl. Sci. Res. 2012, 2, 2909-2922.

70. Institute of Social and Policy Sciences. Public Financing of Education in Pakistan and Agenda for Education Budget 2016-17; Institute of Social and Policy Sciences: Islamabad, Pakistan, 2016.

71. Bontis, N. Intellectual capital: An exploratory study that develops measures and models. Manag. Decis. 1998, 36, 63-76. [CrossRef] 
72. Curado, C. Perceptions of knowledge management and intellectual capital in the banking industry. J. Knowl. Manag. 2008, 12, 141-155. [CrossRef]

73. Muttakin, M.B.; Khan, A.; Mihret, D.G. The Effect of Board Capital and CEO Power on Corporate Social Responsibility Disclosures. J. Bus. Ethics 2016, 150, 41-56. [CrossRef] 